\title{
Prohibitins, novel vitamin K2 target factors in osteoblast
}

\author{
Tatsuya Uebi ${ }^{1}$, Makoto Umeda ${ }^{1}$, Naoya Maekawa ${ }^{1}$, Satoshi Karasawa ${ }^{2}$, Hiroshi Handa ${ }^{2}$, Takeshi Imai ${ }^{1}$ \\ ${ }^{1}$ Department of Aging Intervention, National Center for Geriatrics and Gerontology (NCGG), Obu, Japan \\ ${ }^{2}$ Faculty of Bioscience and Biotechnology, Tokyo Institute of Technology, Yokohama, Japan \\ Email: dai.ncgg@gmail.com
}

Received August 2013

\begin{abstract}
Vitamin $\mathrm{K} 2$ (VK2, menaquinone) is a drug for osteoporosis. VK2 acts as a cofactor for $\gamma$-glutamyl carboxylase, which catalyzes the carboxylation of specific glutamic acid residues ( $\gamma$-carboxylation) of substrate proteins. Here we demonstrate that VK2 also regulate osteoblastgenic marker gene expression. Using VK2immobilzed nanobeads new target proteins were purified and identified from osteoblastic cell line. They are prohibitin 1 and 2 (PHB1 \& 2), respectively. To confirm the PHBs function on VK2-dependent transcription, PHB1 \& 2 were knock-down and osteocalcin gene 2 transcriptions were analyzed, indicating that PHBs regulate VK2-dependent transcription. Taken together PHBs are VK2 target proteins for osteoblastgenic transcription.
\end{abstract}

Keywords: Vitamin K2; Prohibitin; Osteoblast; Runt-Related Transcription Factor 2 (Runx2)

\section{INTRODUCTION}

Vitamin $\mathrm{K}(\mathrm{VK})$ is a fat-soluble vitamin that was discovered in 1929 [1]. There are three types of VK: naturally occurring VK1 (phylloquinone) and VK2 (menaquinone, MK) and chemically synthesized VK3 (menadione). VK2 is also known as MK-n ( $=1$ to 14), where $n$ stands for the number of repeating isoprenyl units in its side chain [2]. The most common form of VK in animals is MK-4, which is produced by intestinal bacteria or is metabolically converted from other VKs [3]. VK was originally discovered as an essential factor for blood coagulation [4]. VK acts as a cofactor for $\gamma$-glutamyl carboxylase, which catalyzes the carboxylation of specific glutamic acid residues ( $\gamma$-carboxylation) of substrate proteins. VK-dependent $\gamma$-carboxylation plays an important role in bone homeostasis. Osteocalcin, a critical regulator of calcium uptake and bone mineralization in osteoblasts, is activated by $\gamma$-carboxylation [5]. Vitamin $\mathrm{K}$ deficiency causes bleeding diathesis, particularly in newborn babies [6]. In addition, undercarboxylation of osteocalcin due to vitamin $\mathrm{K}$ deficiency is thought to result in osteoporosis [7]. Thus, MK-4, one of the most potent VKs, has been widely used as a therapeutic drug for the above-mentioned diseases [8].

In all the in vitro study VK2 concentration is generally too high $(10-100 \mu \mathrm{M})$, suggesting that there is other VK2 target protein(s) with higher affinity to VK2. So, we selected osteoblast cell system among several systems, because VK2 effect was significantly detected in $10 \mathrm{nM}$ concentration.

\section{MATERIALS AND METHODS}

\subsection{Cell Culture \& Extract}

Mouse calvaria-derived osteoblastic cell line MC3T3-E1 [9] was maintained in $\alpha$-minimal essential medium supplemented with $10 \%$ fetal calf serum. Cells were plated at a density of $1.5 \sim 3 \times 10^{6}$ cells/60-mm dish and, after 48 hours, re-fed with the same medium supplemented with $0.5 \%$ fetal calf serum. After 24 hours, the cells were treated with various reagents or an equal volume of vehicle [10,11].

MC3T3-E1 cells were cultivated and harvested. The cell pellets were washed with PBS several times, and solubilized with binding buffer ( $20 \mathrm{mM}$ HEPES-NaOH

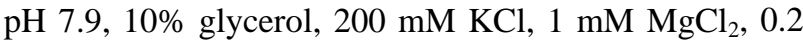
$\mathrm{mM} \mathrm{CaCl} 2,0.2 \mathrm{mM}$ EDTA, $1 \mathrm{mM}$ DTT and $0.2 \mathrm{mM}$ PMSF) with $1 \% n$-octyl- $\beta$-D-glucoside ( $n$-octylglucoside), and centrifuge $1300 \mathrm{~g}$ for 5 minutes and supernatant was recovered. The supernatant was dialyzed against binding buffer for 4 hours for elimination of $n$-octylglucoside. The nuclear extract was prepared according to the method of Dignam et al. [12] for immuno-precipitation interaction experiments in nuclear.

\subsection{Alkaline Phosphatase Assay}

MC3T3-E1 cells were cultivated in 24-well plates. After reaching confluency, medium was supplemented with 60 $\mu \mathrm{g} / \mathrm{mL}$ ascorbic acid and $10 \mathrm{nM}$ dexamethasone and cultured for 7 more days. Cells were harvested and analyzed their alkaline phosphatase activity using commercial kit (Reporter Assay kit, SAK-101, TOYOBO) with manu- 
facturing protocols.

\subsection{Luciferase Analysis}

The luciferase analysis was performed with manufacture's (Promega) introduction described previously [13]. Mutated OSE2 site was replaced

5'-gcaatcacc-ACCACA-gcatc-3' (-137 - -130) to BamHI site (5'-gcaatcacc-GAATTC-gcatc-3') in the OG2 promoter [14-16].

\subsection{Vectors}

Runx2 over expression vector was kindly provided from Pr Komori [17]. The shRunx2 and shPHB1 vectors were purchased from SantaCruz. For the expression of shPHB2 RNA, the mouse U6 promoter (positions -315 to +5 ) was cloned into pBluescript SK+. A doublestranded oligonucleotide was inserted downstream of the promoter so as to express the following RNA; 5'CCACATCACAGAACCGAATCTATC-ttcaagaga-GATAGATTCGGTTCTGTGATGTGG-3' (942 - 965 bp of NM_007531.2).

\subsection{VK2-Immobilized Beads}

FG beads were prepared as previously described $[13,18]$. Epoxy groups on FG beads were aminolyzed by $\mathrm{NH}_{4} \mathrm{OH}$ and coupled to ethylene glycol diglycidyl ether (EGDE) to produce FGNEGDE beads. Epoxy groups on FGNEGDE beads were aminolyzed by $\mathrm{NH}_{4} \mathrm{OH}$ to produce FGNEGDEN beads. FGNEGDEN beads $(5.0 \mathrm{mg}$ ) were incubated with $5.0 \mathrm{mM}$ VK2 in $500 \mu \mathrm{L}$ of DMF containing EDC, triethylamine and DMAP at $25^{\circ} \mathrm{C}$ for 24 hours. Unreacted amino groups on the surface of the beads were masked with acetic anhydride in DMF containing triethylamine at $25^{\circ} \mathrm{C}$ for 24 hours. VK2-immobilized beads were suspended in distilled water and stored at $4^{\circ} \mathrm{C}$ until use $[2,19]$.

\subsection{Statistical Analysis}

Values are reported as mean + SEM. Statistical significance $\left({ }^{*} \mathrm{p}<0.05 ;{ }^{* *} \mathrm{p}<0.005 ;{ }^{* * *} \mathrm{p}<0.0001\right)$ was shown. Non-statistical differences $(\mathrm{p}>0.05)$ were shown as NS (non-significance).

\section{RESULTS AND DISCUSSION}

\subsection{VK2 Induces Osteoblast Differentiation Markers (Figure 1)}

VK2 was administrated to the osteoblastic cell line MC3T3-E1, and its osteoblast differentiation markers were analyzed. First, alkaline phosphatase (ALP) activity was analyzed in several doses $(\sim 1 \mu \mathrm{M})$ of VK2. ALP activity was significant and 3.5-fold induced in a dose
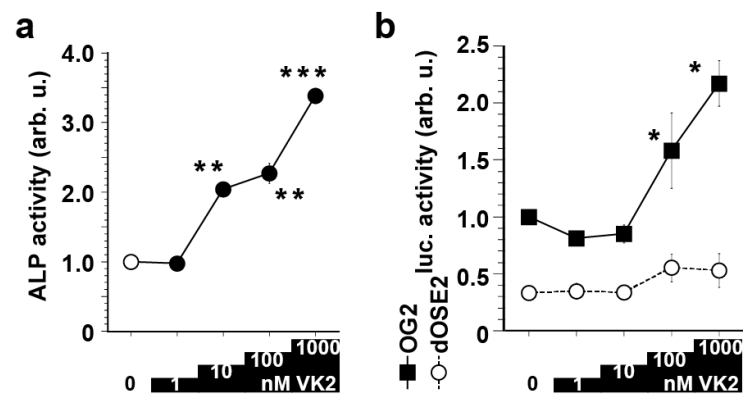

Figure 1. VK2 induces osteoblast differentiation markers. VK2 was administrated to osteoblastic cell line MC3T3E1, and the cell activities of ALP (a), OG2-luciferase and dOSE2-luciferase (b) were analyzed. The VK2 concentration was 0 (vehicle), 1, 10, 100 and $1000 \mathrm{nM}$ (A), respectively. Values are expressed as the mean + SEM ( $\mathrm{n}=$ 5). ${ }^{*} \mathrm{p}<0.05 ;{ }^{* *} \mathrm{p}<0.005 ;{ }^{* * *} \mathrm{p}<0.0001$.

dependent manner (Figure 1(a)). Similar results were obtained in the other osteoblast markers of osteocalcin gene2 (OG2) promoter activities, especially OSE2 site [13-15], resulting that VK2 induced osteoblast differentiation in transcriptional level. VK2 regulates Rnux2 activity. Runx2 point mutant or heterozygotes results in Cleidocranial Dysplasia (CCD; [17,20]). Our data showed that VK2 induces Runx2 activity, suggesting that VK2 have possibility to apply to CCD therapy.

\subsection{Preparation of VK2-Immobilized Beads (Figure 2(a))}

To purify new target for VK2, we prepared VK2-immobilized beads. A schematic representation of the procedure for conjugating VK2 to FG-beads is depicted in Figure 2(a). Briefly, epoxy groups on FG beads were aminolyzed by $\mathrm{NH}_{4} \mathrm{OH}$ and coupled to EGDE to produce FGNEGDE beads. EGDE, introduced as a spacer is important for reduction of steric hindrance. Epoxy groups on FGNEGDE beads were aminolyzed by $\mathrm{NH}_{4} \mathrm{OH}$ to produce FGNEGDEN beads. VK2 was then conjugated to FGNEGDEN beads.

\subsection{Purification and Identification of VK2 Target Proteins (Figures 2(b)-(d))}

Using VK2-immobilzed nanobeads, new target proteins were purified from MC3T3-E1 cell extracts directly. LCMS analysis showed that 2 protein bands are corresponded to prohibitin 1 and 2 (PHB1 and PHB2), respectively. No polypeptide from Runx2 was obtained, suggesting that VK2 binds to PHBs and regulates Runx2 activity.

\subsection{PHBs Regulate VK2-Dependent Runx2 Transcriptional Activity (Figure 3)}

PHBs are known as estrogen (E2)-dependent transcrip- 
a

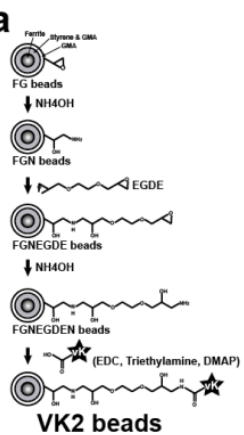

b

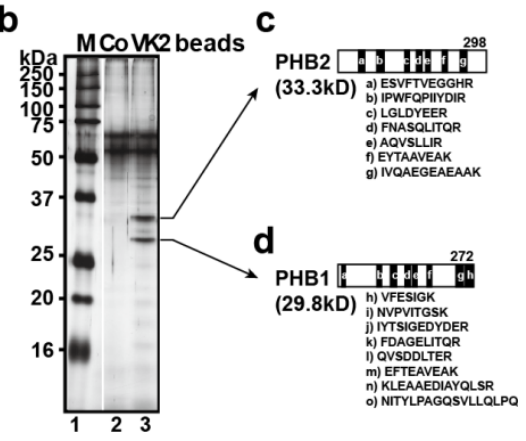

Figure 2. VK2-immobilized beads preparation and purification of new VK2 target proteins. (a) Preparation of VK2-immobilized nanobeads. Epoxy groups on FG beads were aminolyzed by $\mathrm{NH}_{4} \mathrm{OH}$ (FGN beads) and coupled to EGDE to produce FGNEGDE beads. Epoxy groups on FGNEGDE beads were aminolyzed by $\mathrm{NH}_{4} \mathrm{OH}$ to produce FGNEGDEN beads. FGNEGDEN beads were then coupled with carboxyl groups of 15dPGJ2 in DMF containing EDC, triethylamine and DMAP; (b) Purification of VK2 target proteins from MC3T3 E1 cell extracts directly. The cell extracts were mixed with VK2-immobilized beads (K2, lane 3 ) or control beads (Co, lane 2), and bound proteins were separated by SDS-PAGE (5\% - 20\% gradient gel) and visualized by silver staining; (c) and (d) Identification of new VK2 target proteins. Seven (a-g) and eight (h-o) polypeptides were identified by ion-spray mass spectrometry. Identified amino acid sequences are indicated.

a

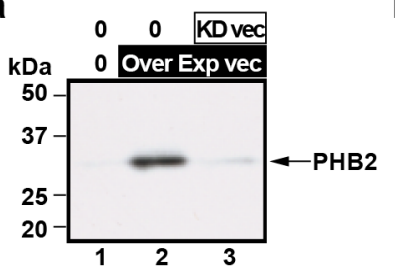

b

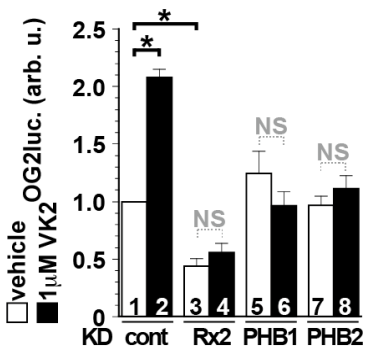

Figure 3. PHBs regulate VK2-dependent transcription activity. (a) Evaluation of PHB2 over expression and knock down vectors. The control vectors (lanes 1 \& 2), PHB2 over expression vectors (lanes $2 \& 3$ ) and shPHB2 vectors (lane 3 ) were transfected to HEK293 FT cells. The cells were extracted and lysates were subjected into SDS-PAGE and Western blotted with anti-PHB2 antibody; (b) New VK2 target proteins PHBs regulate VK2-dependent OG2 transcription. Vehicle (columns 1, 3, $5 \&$ 7) and $1 \mu \mathrm{M}$ VK2 (lanes 2, 4, 6 \& 8) were administrated to MC3T3-E1 cells. Control (columns 1 \& 2), Runx2 (columns 3 \& 4), PHB1 (columns 5 \& 6) and PHB2 (columns 7 \& 8) sh vectors were introduced to the cells, and analyzed luciferase activities. Values are expressed as the mean + SEM $(n=5) .{ }^{*} \mathrm{p}$ $<0.05$, and NS, $\mathrm{p}>0.05$ not significant.

tion regulators [21], but Runx2-interaction was not reported. First, PHB2 over expression and knock-down (KD) vectors were established. They were introduced into HEK293FT cells, and PHB2 proteins were detected (Figure 3(a)). Functions of the 2 vectors were confirmed. Using KD vectors, contribution of Runx2 and PHBs on

OG2 transcription was analyzed. Without VK2 (columns 1, 3, 5 \& 7) only Runx2 KD reduced significantly OG2 transcription, suggesting that PHBs do not affect on basal OG2 activity, but Runx2 regulates basal OG2 transcription via OSE2 (Figure 1(b)). In the meanwhile, control $\mathrm{KD}$ vector introduction significantly induced luciferase activity by VK2 induction (columns 1 and 2), but in the case of other KD vectors (Runx2 \& PHBs) no significant induction was observed by VK2 administration, indicating that Runx2, PHB1 \& PHB2 are contributed to the VK2-dependent transcription.

PHB2 was identified as Estrogen Receptor $\alpha(\mathrm{ER} \alpha)$ modulator, and PHB2 regulates not only ER $\alpha$ function, but also other transcription factors [21], indicating that one example is Runx2, which we show here, ER $\alpha$ and other possibility. As next step, other down stream factor of PHBs will be identified.

\section{CONCLUSION}

The concentration of VK2 on osteoblastgenesis is lower than others, less than $1 \mu \mathrm{M}$. VK2 induced osteoblastgenic activities. One of the VK2 signaling pathways is mediated through the Runx2 activity. To identify the VK2 target protein(s) VK2-immobilized nanobeads were established, and 2 proteins, PHB1 and 2, were purified from osteoblast cell extracts directly. By OG2 reporter analysis with KD vectors, PHB1 \& 2 are responsible for VK2-dependent OG2-transcription. Taken together, PHB1 \& 2 are new VK2 target proteins in osteoblastgenesis.

\section{ACKNOWLEDGEMENTS}

We thank to Pr Komori for Runx2 vectors. We are grateful to our department members in NCGG for helpful discussions. This work was supported by a Grant-in-Aid for the Ministry of Education, Culture, Sports, Science and Technology.

\section{REFERENCES}

[1] Dam, H. (1929) Cholesterinstoffwechsel in huhnereiern und hähnchen. Biochemische Zeitschrift, 215, 475-492.

[2] Karasawa, S., Azuma, M., Kasama, T., Sakamoto, S., Kabe, Y., Imai, T., Yamaguchi, Y., Miyazawa, K. and Handa, H. (2013) Vitamin K2 covalently binds to Bak and induces Bak-mediated apoptosis. Molecular Pharmaceutics, 83, 613-620. http://dx.doi.org/10.1124/mol.112.082602

[3] Seegers, W.H. and Bang, N.U. (1967) Blood clotting enzymology. Academic Press, New York.

[4] Dam, H. (1935) The antihaemorrhagic vitamin of the chick. Biochemical Journal, 29, 1273-1285.

[5] Hauschka, P.V., Lian, J.B. and Gallop, P.M. (1975) Direct identification of the calciumbinding amino acid, gamma-carboxyglutamate, in mineralized tissue. Proceedings of the National Academy of Sciences of the 
United States of America, 72, 3925-3929.

http://dx.doi.org/10.1073/pnas.72.10.3925

[6] Thorp, J.A., Gaston, L., Caspers, D.R. and Pal, M.L. (1995) Current concepts and controversies in the use of vitamin K. Drugs, 49, 376-387. http://dx.doi.org/10.2165/00003495-199549030-00005

[7] Iwamoto, J., Takeda, T. and Sato, Y. (2004) Effects of vitamin K2 on osteoporosis. Current Pharmaceutical Design, 10, 2557-2576. http://dx.doi.org/10.2174/1381612043383782

[8] Ushiroyama, T., Ikeda, A. and Ueki, M. (2002) Effect of continuous combined therapy with vitamin $\mathrm{K}(2)$ and vitamin $\mathrm{D}(3)$ on bone mineral density and coagulofibrinolysis function in postmenopausal women. Maturitas, 41, 211-221. http://dx.doi.org/10.1016/S0378-5122(01)00275-4

[9] Sudo, H., Kodama, H., Amagai, Y., Yamamoto, S. and Kasai, S. (1983). In vitro differentiation and calcification in a new clonal osteogenic cell line derived from newborn mouse calvaria. The Journal of Cell Biology, 96, 191198. http://dx.doi.org/10.1083/jcb.96.1.191

[10] Takai, H., Kanematsu, M., Yano, K., Tsuda, E., Higashio, K., Ikeda, K., Watanabe, K. and Yamada, Y. (1998) Transforming growth factor-beta stimulates the production of osteoprotegerin/osteoclastogenesis inhibitory factor by bone marrow stromal cells. The Journal of Biological Chemistry, 273, 27091-27096. http://dx.doi.org/10.1074/jbc.273.42.27091

[11] Jochum, W., David, J.P., Elliott, C., Wutz, A., Plenk Jr., H., Matsuo, K. and Wagner, E.F. (2000). Increased bone formation and osteosclerosis in mice overexpressing the transcription factor Fra-1. Nature Medicine, 6, 980-984. http://dx.doi.org/10.1038/79676

[12] Dignam, J.D., Lebovitz, R.M. and Roeder, R.G. (1983) Accurate transcription initiation by RNA polymerase II in a soluble extract from isolated mammalian nuclei. Nucleic Acids Research, 11, 1475-1489. http://dx.doi.org/10.1093/nar/11.5.1475

[13] Maekawa, N., Hiramoto, M., Sakamoto, S., Azuma, M., Ito, T., Ikeda, M., Naitou, M., Acharya, H.P., Kobayashi, Y., Suematsu, M., Handa, H. and Imai, T. (2011) Highperformance affinity purification for identification of 15deoxy- $\Delta 12,14-\mathrm{PGJ}_{2}$ interacting factors using magnetic nanobeads. Biomedical Chromatography, 25, 466-471. http://dx.doi.org/10.1093/nar/11.5.1475
[14] Ducy, P. and Karsenty, G. (1995) Two distinct osteoblast-specific cis-acting elements control expression of a mouse osteocalcin gene. Molecular and Cellular Biology, 15, 1858-1869.

[15] Geoffroy, V., Ducy, P. and Karsenty, G. (1995) A PEBP2a/AML-1-related factor increases osteocalcin promoter activity through its binding to an osteoblast-specific cis-acting element. The Journal of Biological Chemistry, 270, 30973-30979. http://dx.doi.org/10.1074/jbc.270.52.30973

[16] Ducy, P., Zhang, R., Geoffroy, V., Ridall, A.L. and Karsenty, G. (1997) Osf2/Cbfa1: A transcriptional activator of osteoblast differentiation. Cell, 89, 747-754. http://dx.doi.org/10.1016/S0092-8674(00)80257-3

[17] Komori, T., Yagi, H., Nomura, S., Yamaguchi, A., Sasaki, K., Deguchi, K., Shimizu, Y., Bronson, R.T., Gao, Y.H., Inada, M., Sato, M., Okamoto, R., Kitamura, Y., Yoshiki, S. and Kishimoto, T. (1997). Targeted disruption of Cbfa1 results in a complete lack of bone formation owing to maturational arrest of osteoblasts. Cell, 89, 755-764. http://dx.doi.org/10.1016/S0092-8674(00)80258-5

[18] Hiramoto, M., Maekawa, N., Kuge, T., Ayabe, F., Watanabe, A., Masaike, Y., Hatakeyama, M., Handa, H. and Imai, T. (2010) High-performance affinity chromatography method for identification of L-arginine interacting factors using magnetic nanobeads. Biomedical Chromatography, 24, 606-612. http://dx.doi.org/10.1002/bmc.1334

[19] Umeda, M., Uebi, T., Maekawa, N., Masaike, Y., Handa, H. and Imai, T. (2013) Effective cofactor complex purification using nanobeads. Journal of Bioscience and Medicine, in Press.

[20] Otto, F., Thornell, A.P., Crompton, T., Denzel, A., Gilmour, K.C., Rosewell, I.R., Stamp, G.W.H., Beddington, R.S.P., Mundlos, S., Olsen, B.R., Selby, P.B. and Owen, M.J. (1997). Cbfa1, a Candidate gene for cleidocranial dysplasia syndrome, is essential for osteoblast differentiation and bone development. Cell, 89, 765-771. http://dx.doi.org/10.1016/S0092-8674(00)80259-7

[21] He, B., Feng, Q., Mukherjee, A., Lonard, D.M., DeMayo, F.J., Katzenellenbogen, B.S., Lydon, J.P. and O’Malley, B.W. (2008) A repressive role for prohibitin in estrogen signaling. Molecular Endocrinology, 22, 344-360. http://dx.doi.org/10.1210/me.2007-0400 